\title{
PEMBERIAN MINUMAN JAHE TERHADAPTEKANANDARAH PENDERITA HIPERTENSI DI POSYANDU LANSIA SURYA KENCANA BULAK JAYA SURABAYA
}

\author{
Rina Budi Kristiani' ${ }^{1}$, Sindi Surya Ningrum ${ }^{2}$ \\ Prodi D3 Keperawatan STIKes Adi Husada \\ Jl. Kapasari No. 95, Kel. Kapasan, Kec. Simokerto, Surabaya, Jawa Timur, Indonesia \\ rinabudikristiani.rb@gmail.com
}

\begin{abstract}
Abstrak
Hipertensi adalah faktor risiko utama yang dapat dimodifikasi untuk mencegah terjadin ya penyakit kardiovaskular dan kematian, terutama pada orang lanjut usia. Peningkatan tekanan darah pada lansia dipengaruhi oleh hilangnya jaringan elastis di arteri dan peningkatan kekakuan arteri secara bersamaan. Penatalaksanaan hipertensi yaitu melakukan perubahan gaya hidu p dengan me mbatasi konsumsi alkohol dan natrium, berhenti merokok, meningkatkan aktivitas fisik dan men gatur pola makan. Terapi yang akan digunakan yaitu terapi pemberian minuman jahe. Tujuan penelitian un tuk mengtahui pengaruh terapi pemberian minuman jahe terhadap tekanan darah penderita hiperten si di posyandu lansia Suraya Kencana. Desain penelitian ini Quasy Eksperimental men ggunakan model Non equivalent Control Group Design. Sampel penelitian ini adalah lansia penderita hipertensi tan pa memiliki riwayat penyakit hiperkalemia, penyakit ginjal dan gastritis sebanyak 30 responden. Penentuan sampel menggunakan simple random sampling. Analisa data menggunakan uji MannWhitney U. Sebagian besar responden berusia 60-65 tahun, perempuan, memiliki riway at penyakit kolesterol. Hasil tekanan darah kelompok intervensi sebelum pemberian minuman jahe pada hipertensi Grade 1 sebanyak 66,6\% dan sesudah dilakukan terapi kategori Pre Hiperten si berjumlah $46,6 \%$. Hasil uji statistik nilai p value $=0,000(<0,05)$ dan nilai $Z$ hitung -3.758 yang menunjukkan ada pengaruh pemberian minuman jahe terhadap tekanan darah penderita hipertensi. Pemberian minuman jahe dapat digunakan sebagai alternatif mengontrol tekanan darah pada penderita hipertensi dan mudah dilakukan secara mandiri karena bahan yang dibutuhkan mudah didapat dan terjangkau.
\end{abstract}

Kata Kunci :Minuman Jahe, Tekanan Darah, Lansia, Hipertensi

\begin{abstract}
Hypertension is a major modifiable risk factor to prevent cardiovascular disease and death, especially in the elderly. The increase in blood pressure in the elderly is affected by the loss of elastic tissue in the arteries and a concomitant increase in arterial stiffness. Management of hypertension is making lifestyle changes by limiting alcohol and sodium consumption, quitting smoking, increasing physical activity and adjusting diet. The therapy that will be used is ginger drink therapy. The aim of the study was to determine the effect of ginger drink therapy on blood pressure of hypertensive patients at the posyandu for elderly Suraya Kencana. The design of this research is Quasy Experimental using the Nonequivalent Control Group Design model. The sample of this study was 30 elderly people with hypertension without a history of hyperkalemia, kidney disease and gastritis. Determination of the sample using simple random sampling. Data analysis used the Mann-Whitney $U$ test. Most of the respondents aged 60-65 years, women, had a history of cholesterol disease. The results of blood pressure in the intervention group before giving ginger drink in Grade 1 hypertension were $66.6 \%$ and after doing the Pre Hypertension category therapy amounted to $46.6 \%$. The statistical test results $p$ value $=0.000(<0.05)$ and the $Z$ value count $-3,758$ which shows that there is an effect of ginger drink on the blood pressure of hypertensive patients. Giving ginger drink can be used as an alternative to control blood pressure in patients with hypertension and is easy to do independently because the ingredients needed are easy to obtain and affordable. .
\end{abstract}

Keywords: Ginger Drink, Blood Pressure, Elderly, Hypertension

Corresponding author:

Rina Budi Kristiani

rinabudikristiani.rb@gmail.com 


\section{PENDAHULUAN}

Tekanan darah akan meningkat seiring dengan bertanbahnya usia. Usia diatas 55 tahun memiliki risiko mengalami hipertensi seumur hidup sebanyak 90\% (Bell, Twiggs, \& Olin, 2015). Faktor penyebab peningkatan tekanan darah adalah hilangnya jaringan elastis dan kekakuan pada pembuluh darah arteri (Wing \& Gabb, 2018). Faktor risiko tambahan lainnya yang terkait erat dengan usia lanjut adalah kelemahan, obesitas, dan diabetes. Penurunan kadarh ormon mungkin memainkan peran penting dalam perkembangan CVD pada pria dan wanita (Rodgers et al., 2019).

Hipertensi adalah beban dunia, Namun itu adalah faktor yang paling dapat dimodifikasi dalam penyakit kardiovaskular. Hipertensi adalah salah satu penyebab utama kematian, karena mungkin asimptomatik tetapi banyak komplikasi akan berkembang dengan cepat dan mengarah pada kematian. Pencegahan dan pengendalian hipertensi akan menurunkan angka kematian, dan gagal jantung (Salem et al., 2018).

Angka kejadian hipertensi di dunia sebesar 970.000 .000 orang dan dip erkirakan pada tahun 2025 akan meningkat menjadi 1,56 milyard orang dewasa akan hidup dengan hipertensi (Bell et al., 2015). Jumlah penderita hipertensi di Indoesia pada usia 55-64 tahun sebesar $55,2 \%$ dan terus meningkat seiring dengan bertambahnya usia dan jumlah penderita hipertensi di kota Surabaya mencapai 22,0\% (Riskesdas, 2018). Hasil survey awal yang telah dilakukan di Posyandu Lansia Surya Kencana pada 5 orang penderita hipertensi menyatakan tindakan yang dilakukan jika sedang sakit kepala 4 orang hanya istirahat dan 1 orang berobat ke puskesmas.

Penatalaksanaan hipertensi dapat dilakukan dengan pemberian obat seperti diuretik, beta-blocker, Angiotensin receptor blocker, vasodilator langsung dan melakukan perubahan gaya hidup, membatasi asupan garam, Modifikasi diet (lemak, karbohidrat, protein, kolesterol, serat, kalsium dan magnesium), tinggi buah dan sayur, penurunan berat badan, olahraga rutin, berhenti merok ok (Manuntung, 2019). Terapi hipertensi farmakologis dapat menimbulkan efek samping seperti angioedema, batuk kering, lemas, sakit kepala, dll. dengan demikian, ada kebutuhan untuk bentuk terapi pengganti untuk penderita tekanan darah tinggi. Produkproduk herbal menjadi sangat berguna dan diarahkan untuk mengobati tekanan darah, dan contoh penting dari tanaman tersebut adalah jahe.

Jahe mengandung senyawa kimia Gingerol yang digunakan untuk memblock viltase-saluran kalsium yang ada didalam sel pembuluh darah sehingga akan terjadi vasodilatasi atau vasokontriksi pembuluh darah yang merangsang penurunan kontraksi otot polos dinding arteri sehingga akan menyebabkan penurunan tekanan darah. Jahe juga mengandung Kalium yang menghambat pelepasan renin Angiotensin yang akan meningkatkan ekskresi natrium dan airs sehingga retensi natrium dan air didalam darah berkurang dan akan terjadi penurunan tekanan darah (Braga, 2019).

Berdasarkan keterangan diatas, peneliti tertarik untuk melakukan penelitian tentang "Pengaruh Pemberian Minuman Jahe Terhadap Tekanan Darah Penderita Hipertensi Di Posyandu Lansia Surya Kencana Bulak Jaya Surabaya".

\section{METODE PENELITIAN}

Metode penelitian adalah Kuasi Eksperimental dengan pre dan post test di Posyandu Lansia Surya Kencana Bulak Jaya Surabaya dengan 30 responden. Pengambilan sampel menggunakan metode Simple Random Sampling. Responden dibagi menjadi 2 kelompok yaitu kelompok intervensi diberikan minuman jahe 1 kali perhari dengan jumlah $100 \mathrm{cc}$ selama 5 hari berturut-turut dan kelompok kontrol. Dalam penelitian ini menggunakan lembar kuisioner dan lembar observasi tekanan darah, dianalisis menggunakan uji Wilcoxon dan MannWhitney. 
HASIL

Tabel 1

Distribusi Karakteristik Responden di Posyandu Lansia Surya Kencana Surabaya

\begin{tabular}{|c|c|c|c|c|c|}
\hline \multirow[t]{2}{*}{ No } & \multirow[t]{2}{*}{ Data } & \multicolumn{2}{|c|}{ Kelompok Intervensi } & \multicolumn{2}{|c|}{ Kelompok Kontrol } \\
\hline & & $\mathbf{F}$ & $\mathbf{P}$ & $\mathbf{F}$ & $\mathbf{P}$ \\
\hline \multirow[t]{4}{*}{1.} & Jenis Kelamin & & & & \\
\hline & a. Laki-laki & 4 & $26,6 \%$ & 5 & $33,3 \%$ \\
\hline & b. Perempuan & 11 & $73,3 \%$ & 10 & $66,6 \%$ \\
\hline & Jumlah & 15 & $100 \%$ & 15 & $100 \%$ \\
\hline \multirow[t]{4}{*}{2.} & Usia & & & & \\
\hline & a. 60-65 Tahun & 11 & $73,3 \%$ & 12 & $80 \%$ \\
\hline & b. 66-74 Tahun & 4 & $26,6 \%$ & 3 & $20 \%$ \\
\hline & Jumlah & 15 & $100 \%$ & 15 & $100 \%$ \\
\hline \multirow[t]{12}{*}{3.} & Riwayat Penyakit & & & & \\
\hline & a. Maag & 0 & $0 \%$ & 6 & $40 \%$ \\
\hline & b. Penyakit Ginjal & 0 & $0 \%$ & 0 & $0 \%$ \\
\hline & c. Hiperkalemi & 0 & $0 \%$ & 0 & $0 \%$ \\
\hline & d. Asam Urat & 3 & $20,0 \%$ & 0 & $0 \%$ \\
\hline & e. Kolesterol & 3 & $20,0 \%$ & 8 & $53,3 \%$ \\
\hline & f. Stroke & 1 & $6,6 \%$ & 1 & $6,6 \%$ \\
\hline & g. Penyakitjantung & 1 & $6,6 \%$ & 0 & $0 \%$ \\
\hline & h. Vertigo & 1 & $6,6 \%$ & 0 & $0 \%$ \\
\hline & i. $\mathrm{DM}$ & 2 & $13,3 \%$ & 0 & $0 \%$ \\
\hline & j. $\quad$ Tidak Ada & 4 & $26,6 \%$ & 0 & $0 \%$ \\
\hline & Jumlah & 15 & $100 \%$ & 15 & $100 \%$ \\
\hline \multirow[t]{4}{*}{4.} & Merokok & & & & \\
\hline & a. $\mathrm{Ya}$ & 1 & $6,6 \%$ & 5 & $33,3 \%$ \\
\hline & b. Tidak & 14 & $93,3 \%$ & 10 & $66,6 \%$ \\
\hline & Jumlah & 15 & $100 \%$ & 15 & $100 \%$ \\
\hline \multirow[t]{4}{*}{5.} & $\begin{array}{l}\text { Konsumsi } \\
\text { Garam Perhari }\end{array}$ & & & & \\
\hline & a. $<1$ sendok teh & 9 & $60,0 \%$ & 8 & $53,3 \%$ \\
\hline & b. $>1$ sendok teh & 6 & $40,0 \%$ & 7 & $46,6 \%$ \\
\hline & Jumlah & 15 & $100 \%$ & 15 & $100 \%$ \\
\hline \multirow[t]{4}{*}{6.} & $\begin{array}{l}\text { Konsumsi } \\
\text { Obat Hipertensi }\end{array}$ & & & & \\
\hline & a. Rutin & 8 & $53,3 \%$ & 5 & $33,3 \%$ \\
\hline & b. Kadang-kadang & 3 & $20,0 \%$ & 6 & $40,0 \%$ \\
\hline & c. Tidak pernah & 4 & $26,6 \%$ & 4 & $26,6 \%$ \\
\hline & imlah & 15 & $100 \%$ & 15 & $100 \%$ \\
\hline
\end{tabular}

Berdasarkan tabel di atas terbanyak kelompok intervensi berjenis kelamin perempuan sebanyak $73,3 \%$, usia $60-65$ tahun sejumlah $73,3 \%$, tidak memiliki riwayat penyakit $26,6 \%$, tidak merokok sebanyak 93,3\%, konsumsi garam perhari > 1 sendok teh sebanyak 40,0\%, konsumsi obat hipertensi kadang-kadang sebanyak 20,0\% dan tidak pernah sebanyak 4 orang $(26,6 \%)$. Karakteristik terbanyak responden kelompok kontrol yang berjenis kelamin perempuan $66,6 \%$, usia 60-65 tahun sebanyak 80\%, riwayat penyakit kolesterol sebanyak $53,3 \%$, merokok sebanyak 33,3\%, konsumsi garam >1 sendok teh sebanyak 46,6\%, konsumsi obat hipertensi kadang-kadang sebanyak $40 \%$.

\section{Tabel 2}

Perbedaan Tekanan Darah Sebelum dan Sesudah Tindakan Pada Kelompok Kontrol dan Intervensi di Posyandu Lansia Surya Kencana Surabaya

\begin{tabular}{lcc}
\hline \multicolumn{1}{c}{ Kelompok } & Frekuensi & pvalue \\
\hline Kontrol & 15 & 0.317 \\
\hline Intervensi & 15 & 0.002 \\
\hline
\end{tabular}


Tabel 2 pada kelompok kontrol tidak terdapat perbedaan tekanan darah sebelum dan sesudah tindakan sedangkan pada kelompok intervensi ditemukan perbedaan yang ditunjukkan dengan pvalue 0.002 (< $0.05)$

\begin{tabular}{ccccc}
\multicolumn{4}{c}{ Tabel 3 } \\
Perbedaan Tekanan & \multicolumn{2}{c}{$\begin{array}{c}\text { Darah Sesudah Tindakan Pada Kelompok Kontro dan Intervensi di } \\
\end{array}$} \\
& Posyandu Lansia Surya Kencana Surabaya & \\
\hline Variabel & Kelompok & Frekuensi & Mean & pvalue \\
\cline { 1 - 4 } Tekanan Darah & Kontrol & 15 & 10.70 & \multirow{2}{*}{0.001} \\
\cline { 2 - 4 } & Intervensi & 15 & 20.30 & \\
\hline
\end{tabular}

Tabel 3 menunjukkan hasil Uji Mann-Whitney U pada Post Test didapatk an hasil pvalue $=0,000$ $(<0,05)$, hal ini menunjukkan bahwa terdapat pengaruh tekanan darah sesudah diberikan terapi Pemberian Minuman Jahe pada penderita hipertensi di Posyandu Lansia Surya Kencana Surabaya.

\section{PEMBAHASAN}

Hasil penelitian pada responden kelompok control tidak terdapat perbedaan tekanan darah ditunjukan dengan hasil uji beda berpasangan Wilcoxon $0.317(>0.05)$. Hal in i didukung oleh data yang terdapat $76.6 \%$ respondeng yang tidak teratur minum obat dan $53.3 \%$ memiliki kadar kolesterol dalam darah yang tinggi. Hal ini sesuai dengan hasil penelitian sebelumnya yang menyatakan bahwa perubahan gaya hidup dapat memberikan efek yang menguntungk an pada pencegahan dan pengobatan hipertensi, dengan penekanan pada asupan alkohol dan natrium, berhenti merokok, aktivitas fisik dan mengatur pola makan (Cosimo Marcello, Maria Domenica, Gabriele, Elisa, \& Francesca, 2018).

Pada kelompok intervensi setelah diberikan minuman jahe 5 kali per hari selama 5 hari, terdapat perbedaan tekanan darah y an $\mathrm{g}$ ditunjukan dari uji Mann Whitney U dengan pvalue $0.001(<0.05)$. Berdasarkan data diatas ada pengaruh pemberian minuman jahe terhadap tekanan darah lansia yang mengalami hipertensi di Posyandu Lansia Surya Kenc ana Surabaya.

Terapi pemberian Minuman Jahe adalah minuman yang terbuat $d$ ari jahe y ang diseduh menggunakan air panas bisa disajikan hangat/ dingin. Minuman jahe menyegarkan serta memiliki manfaat kesehatan salah satunya untuk menurunkan tekanan darah. Jahe mengandung senyawa kimia Gingerol yang digunaakan untuk memblock viltasesaluran kalsium yang ada didalam sel pembuluh darah sehingga akan terjadi vasodilatasi atau vasokontriksi pembuluh darah yang merangsang penurunan kon traksi otot polos dinding arteri sehingga akan menyebabkan penurunan tekanan darah. Jahe juga mengandung Kalium yang menghambat pelepasan renin Angiotensin yang akan meningkatkan ekskresi natrium dan airs sehingga retensi natrium dan air didalam darah berkurang dan akan terjadi penurunan tekanan darah (Braga, 2019).

Waktu pemberian intervensi dan jumlah minuman jahe yang dikonsumsi harus diperhatikan. Minuman jahe hanya dikonsumsi 1 kali perhari dengan jumlah $100 \mathrm{cc}$ selama 5 hari berturut-turut. Sebelum dilakukan terapi responden diobservasi tekanan darahn ya dan sesudah terapi pemberian Minuman Jahe responden juga diukur kembali tekanan darahnya untuk mengetahui adanya pengaruh terhadap terapi ini. Responden diberikan minuman jahe yang dibuat oleh peneliti sesuai SOP selama penelitian dilakukan dan Peneliti memberikan SOP cara pembuatan minuman jahe kepada responden agar setelah peneliti melakukan intervensi responden dapat melakukan terapi pemberian minuman jahe secara mandiri. Pemberian minuman jahe dapat digunakan sebagai alternatif mengontrol tekanan darah pada penderita hipertensi. Terapi ini mudah dilakukan secara mandiri karena bahan yang dibutuhkan mudah didapat dan terjangkau, serta dapat menurunkan tekanan darah.

\section{KESIMPULAN}

Hasil penelitian ini adalah ada pengaruh pemberian minuman jahe terhad ap tekanan darah pada penderita hipertensi di Posyandu Lansia Surya Kencana Surabaya. Saran untuk insitusi dapat meningkatkan pengetahuan mahasiswa, perawat atau tenaga medis dalam pemberian informasi kesehatan mengenai manfaat jahe sebagai terapi non farmakologis terhadap hipertensi Bagi responden dapat digunakan alternatif untuk mengendalikan tekanan darah. Selain mu dah, terapi pemberian minuman jahe juga murah 
dan dapat efektif dalam menurunkan tek anan darah. Bagi peneliti selanjutnya sebagai referensi pada penelitian selanjutnya dengan membandingkan dengan terapi lain.

\section{DAFTAR PUSTAKA}

Bell, K., Twiggs, J., \& Olin, B. R. (2015). Hypertension : The Silent Killer : Updated JNC-8 Guideline Recommendations. Albama Pharmacy Association, 1-8.

Braga, S. S. (2019). Ginger: Panacea or consumer's hype? Applied Sciences (Switzerland), 9(8). https://doi.org/10.3390/app9081570

Cosimo Marcello, B., Maria Domenica, A., Gabriele, P., Elisa, M., \& Francesca, B. (2018). Lifestyle and Hypertension: An Evidence-Based Review. Journal of Hypertension and Management, 4(1), 110. https://doi.org/10.23937/24743690/1510030

Riskesdas, K. (2018). Hasil Utama Riset Kesehata Dasar (RISKESDAS). Journal of Physics A: Mathematical and
Theoretical, 44(8), 1-200.

https://doi.org/10.1088/1751-

8113/44/8/085201

Rodgers, J. L., Jones, J., Bolleddu, S. I., Vanthenapalli, S., Rodgers, L. E., Shah, K., ... Panguluri, S. K. (2019). Cardiovascular Risks Associated with Gender and Aging. Journal of Cardiovascular Development and Disease, 6(2), 19. https://doi.org/10.3390/jcdd6020019

Salem, H., Hasan, D. M., Eameash, A., ElMageed, H. A., Hasan, S., \& Ali, R. (2018). Worldwide Prevalence of Hypertension: a Pooled Meta-Analysis of 1670 Studies in 71 Countries With 29.5 Million Participants. Journal of the American College of Cardiology, 71(11), A1819. https://doi.org/10.1016/s07351097(18)32360-X

Wing, L. M. H., \& Gabb, G. M. (2018). Treatment of hypertension in older people. Journal of Pharmacy Practice and Research, 48(1), 92-101. https://doi.org/10.1002/jppr.1417 